\title{
HYPERTROFICKÁ PLÚCNA OSTEOARTROPATIA (HPO) AKO SEKUNDÁRNY PREJAV PRAVDEPODOBNEJ TUBERKULÓZY NA KOSTIACH MLADÉHO MUŽA Z NITRY-SELENCA II ${ }^{1}$
}

\author{
Zuzana Hukelová
}

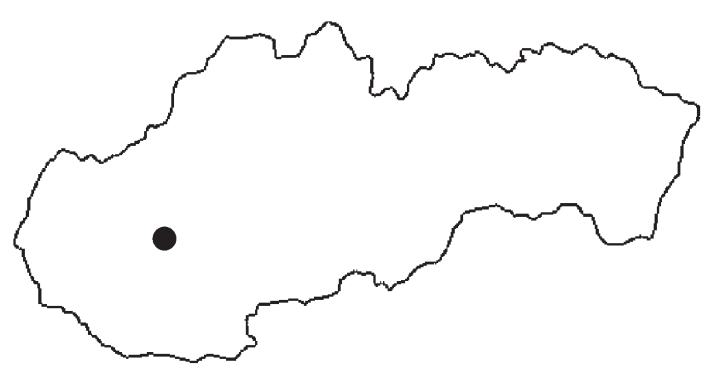

DOI: https://doi.org/10.31577/szausav.2020.67.6

Keywords: Nitra, Middle Ages, palaeopathology, infectious diseases, MOLAT

Hypertrophic pulmonary osteoarthropathy (HPO) as a secondary manifestation of probable tuberculosis in the skeleton of a young man from Nitra-Selenec II

The present study describes human skeletal remains of an individual from the medieval population of Selenec (Nitra district). Macroscopic analysis revealed extensive symmetrical inflammatory changes corresponding with the manifestations of hypertrophic pulmonary osteoarthropathy (HPO). The case from Slovakia therefore represents a welcome addition to the still very limited list of cases of hypertrophic osteoarthropathy observed in human archaeological remains. Taking into account similar cases reported in the world, diagnostic criteria, observed pathological changes, as well as strong association of HPO with tuberculosis (especially with its severe untreated form) and the young age of the individual from Selenec, it is likely that pulmonary tuberculosis was the primary cause of HPO recorded in the man.

\section{ÚVOD}

Predkladaná štúdia sa zaoberá ludskými kostrovými pozostatkami jedinca zo stredovekej populácie z lokality Nitra-Selenec II. Makroskopická analýza odhalila rozsiahle symetrické zápalové zmeny na lebke, povrchu dlhých kostí a rebier, pričom takéto rozmiestnenie lézií odpovedá prejavom tzv. hypertrofickej osteoartropatie (HOA).

HOA je chorobná zmena na povrchu kostí (najčastejšie na telách dlhých kostí), charakteristická symetrickým výskytom rozptýlenej alebo koncentrovanejšej vrstvy novo-vytvorenej kosti. Makroskopicky ide bud' o tenšiu vrstvu pokrývajúcu celý povrch kosti bez viditelného okraja, alebo o novú vrstvu s ostro definovanými hranami pripomínajúcu „záplatu“. Ako samostatné ochorenie je HOA vel'mi zriedkavá a obyčajne sa vyskytuje sekundárne pri ochoreniach plúc, srdca, pečene či čriev (Nayak a i. 2012; Pineda/Martínez-Lavín 2013). Najčastejšie však sprevádza ochorenia plúc, pričom táto forma je známa pod názvom hypertrofická plúcna osteoartropatia (HPO). V dnešnej dobe sú najčastejšími príčinami HPO rakovina a chronická infekcia (Rothschild/Rothschild 1998; 1999). Ako primárna príčina tohto syndrómu bola však opakovane potvrdená neliečená tuberkulóza (Mays/Taylor 2002; Webb/Thomas 1986). Štatisticky bola spojitost' medzi týmito dvoma fenoménmi potvrdená aj v novšej štúdii od S. Assis/A. L. Santos/ C. Roberts (2011), ktorí skúmali portugalskú populáciu z pred-antibiotického obdobia. Tuberkulóza (TBC) je choroba najčastejšie sa vyskytujúca v detstve, u mladých dospelých a starších ludí. Toto ochorenie je známe minimálne od staroveku, ako potvrdzujú ludské pozostatky pochádzajúce už zo starovekého Egypta (Elliot Smith/Ruffer 1910; Palffi a i. 1999). Zmeny skeletu sa v minulosti mohli líšit od moderných klinických diagnostických kritérií špecifických pre TBC (Santos/Roberts 2001), avšak vo všeobecnosti sú najtypickejšími patologickými prejavmi tuberkulózy kolaps a následné zrastenie stavcov, chorobná stuhnutost' (ankylóza) kolenného kíbu, deštrukcia bedrového klbu, absces² bez prejavov zápalu, najmä v oblasti

1 Práca vznikla v rámci grantových projektov VEGA 2/0145/20 „Archeológia, antropológia a pohlavie jedinca ako klúčový atribút pre porozumenie zvykov pravekých spoločností", 2/0124/20 „Ekonomika stredoveku (6.-13. storočie)“ a ako dopadový ukazovatel' udržatel'nosti projektu ITMS: 26220120059.

2 Dutina spôsobená zápalom a vyplnená hnisom. 
Tabela 1. Prípady HOA/HPO v archeologických populáciách vo svete.

\begin{tabular}{|l|l|l|l|}
\hline \multicolumn{1}{|c|}{ Krajina } & \multicolumn{1}{|c|}{ Lokalita } & \multicolumn{1}{c|}{ Datovanie } & \multicolumn{1}{c|}{ Referencia } \\
\hline Izrael & Atlit-Yam & $9250-8160$ BC & Hershkovitz a i. 2008 \\
Mad’arsko & Hódmezövásárhely-Gorzsa & $4850-4550$ cal. BC & Masson a i. 2013 \\
Mexiko & Ticoman & 2000 BC-100 AD & Martínez-Lavín 1997 \\
Mexiko & Maya & $300-900$ AD & Martínez-Lavín 1997 \\
Francúzsko & Les Rues des Vignes & $500-700$ AD (merovejovské obdobie) & Assis a i. 2011 \\
Pol'sko & Czarna Wielka & stredovek & Gladykowska-Rzeczycka/Prejzner 1993 \\
\hline
\end{tabular}

krížovej kosti či na telách stavcov, ako aj vnútrolebečné zmeny (tzv. serpens endocrania symmetrica - SES) a abnormálne odtlačky krvných ciev na vnútorných častiach kostí lebky. Medzi d’alšie zmeny často spojené s TBC, pozorovatel’né na kostiach, patria difúzna symetrická periostitída (zápal povrchu kosti) postihujúca kosti postkraniálneho skeletu, periostitída rebier či hypervaskularizácia tiel stavcov (Maczel 2003), pričom zmeny na rebrách a stavcoch sú pravdepodobne spôsobené infekciou mäkkých tkanív v oblasti hrudníka.

V archeologických populáciách bolo celkovo identifikovaných len niekol'ko prípadov HOA/HPO (tabela 1). Sú známe prípady z Mad’arska (Masson a i. 2013), Francúzska (Blondiaux a i. 1992), Pol’ska (Gladykowska-Rzeczycka/Prejzner 1993) Izraela (Hershkovitz a i. 2008) či Mexika (Martínez-Lavín 1997).

\section{ARCHEOLOGICKÝ KONTEXT}

V rokoch 2009 a 2010 bol v Nitre-Selenci pod vedením Archeologického ústavu SAV v rámci výstavby dial’nice R1 uskutočnený záchranný archeologický výskum (Ruttkay a i. 2013; 2015a; 2015b). Lokalita sa nachádzala asi štyri kilometre od centra Nitry (obr. 1). Boli odkryté tri samostatné náleziská, Selenec I (poloha s malým cintorínom datovaným do obdobia stredoveku), Selenec II (väčší stredoveký cintorín z konca 11. storočia) a Selenec III (pozostávajúci z niekolkých archeologických objek-

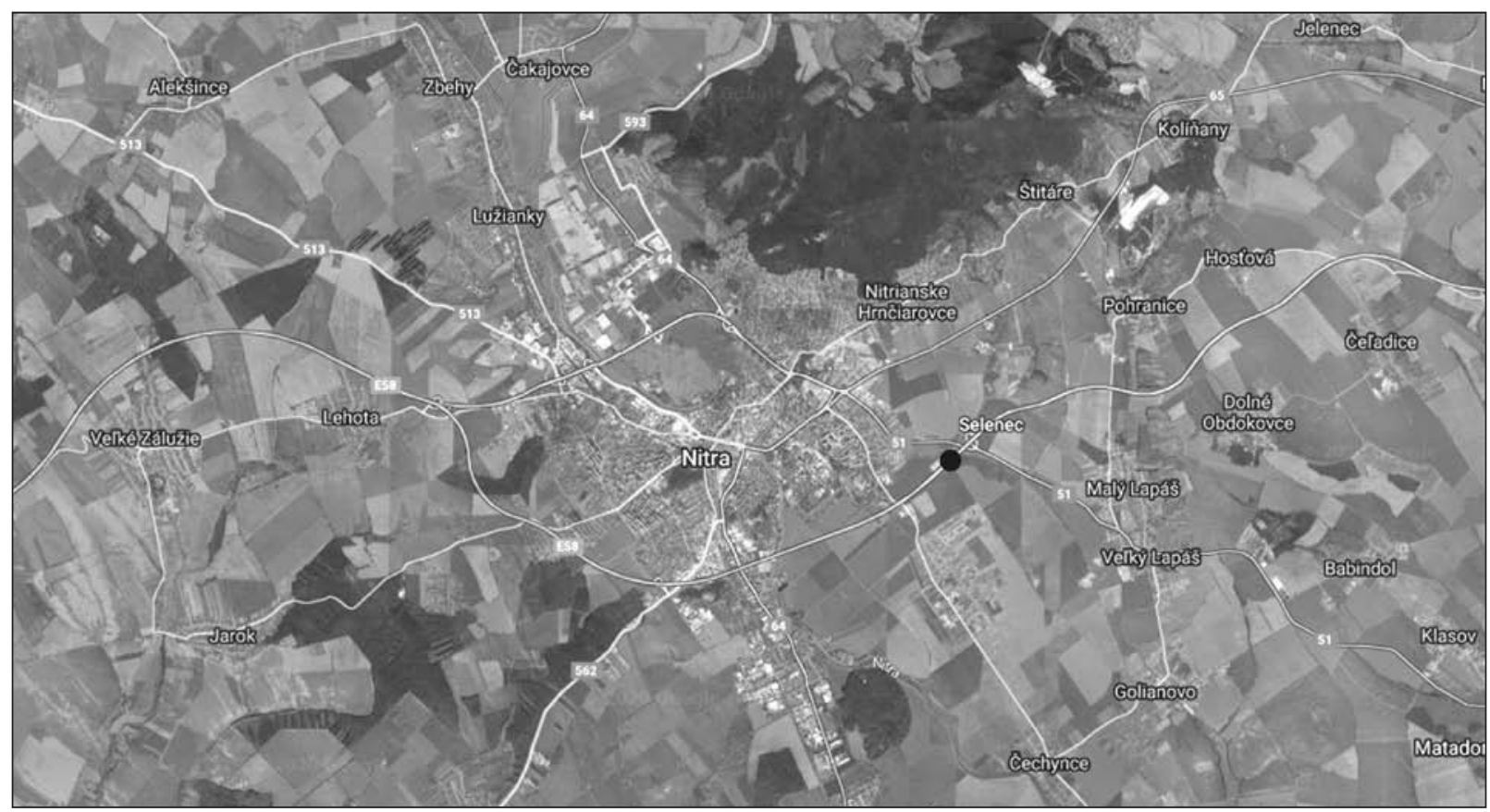

Obr. 1. Poloha lokality Nitra-Selenec II. Dostupné na: https://www.google.com/maps/search/nitra-selenec+mapa/ $@ 48.3059043,18.1355456,1217 \mathrm{~m} /$ data=!3m1!1e3?hl=sk 


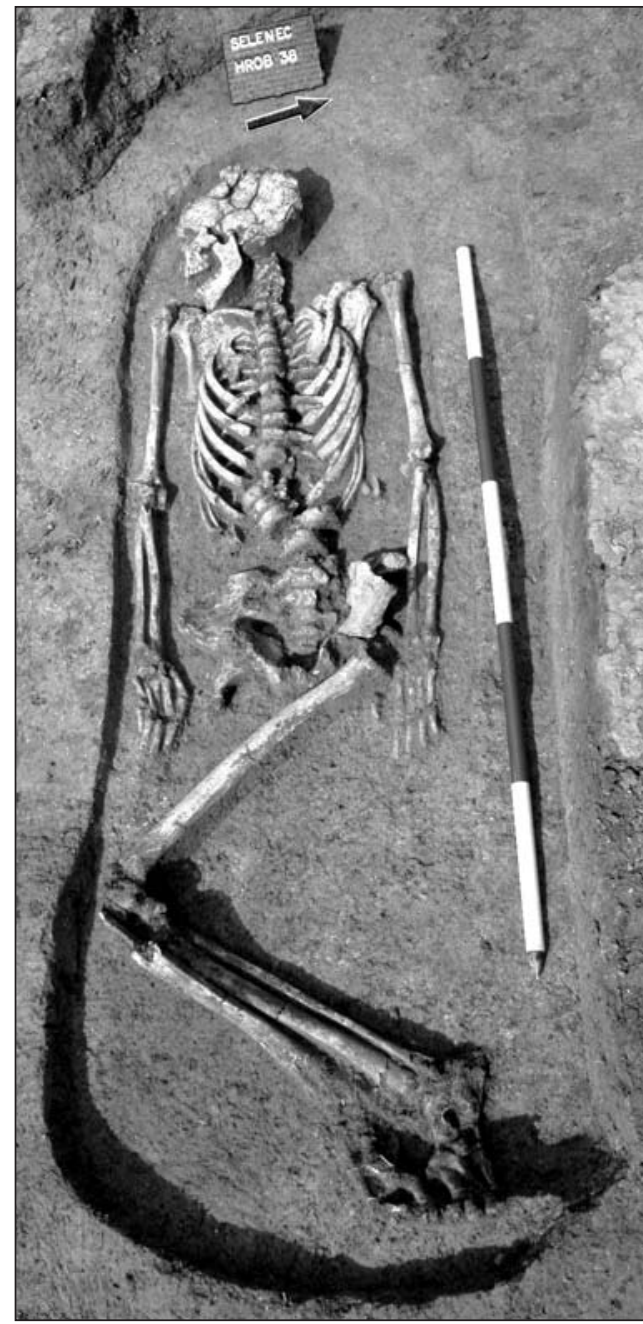

Obr. 2. Uloženie jedinca v hrobovej jame (podla Daňová 2013).

tov z 10.-12. stor.). Dva stredoveké cintoríny (Selenec I, II) boli od seba vzdialené asi $130 \mathrm{~m}$ a predpokladá sa, že predstavovali skôr dve samostatné pohrebiská ako jeden vel'ký cintorín (Daňová 2013, 12). V dôsledku modernej zástavby sa z plochy väčšieho cintorína (Selenec II), z ktorej pochádza aj jedinec z hrobu 38, podarilo preskúmat' len približne polovicu. ${ }^{3}$

Pohrebisko v polohe Selenec II sa nachádzalo na tienistom severnom svahu kopca, východne od potoka Selenec (Daňová 2013). Okrem dvoch hrobov sa l'udské pozostatky nachádzali vo všetkých 63 hrobových jamách, pričom spolu bolo exhumovaných 72 jedincov (Daňová/Ruttkay 2011). Vo väčšine prípadov išlo o hroby jednotlivcov, ktoré boli pravdepodobne usporiadané do radov, hoci počet jám sa líšil v jednotlivých radoch. Zosnulí boli väčšinou umiestnení na chrbte s hlavami na severozápad/západ. Pohrebná výbava bola vo všeobecnosti vel'mi chudobná, zodpovedajúca vtedajšiemu pohrebnému rítu. Minca krála Šalamúna, nájdená v jednom z hrobov, datuje cintorín do druhej polovice 11. storočia (Daňová 2013; Daňovál Ruttkay 2011).

\section{MATERIÁL A POUŽITÉ METÓDY}

Hrob 38 bol situovaný v severnej časti odkrytej plochy pohrebiska, pričom nad ním sa v superpozícii nachádzali dva mladšie hroby (hrob 6 a 11). Jedinec ležal na chrbte, bol uložený hlavou na západ a otočený tvárou na juh. Horné končatiny mal uložené pozdĺž tela, dolné končatiny boli skrčené do pravého uhla, na pravom boku (obr. 2). Hrob neobsahoval žiadny inventár.

Kompletnost' i zachovalost’ kostry boli postačujúce pre určenie základných antropologických atribútov ako aj pre zaznamenanie prípadných patologických zmien.

Pohlavie jedinca bolo odhadnuté na základe morfologických znakov panvy a lebky (Acsádi/Nemeskéri 1970; Brickley/McKinley 2004; Buikstra/Ubelaker 1994; Graw/Czarnetzki/Haffner 1999; Phenice 1969; Rogers/Saunders 1994), pričom takmer všetky morfologické znaky poukazovali na jedinca mužského pohlavia.

Epifýzy dlhých kostí neboli ešte úplne prirastené k dlhým kostiam, išlo zjavne o adolescentného jedinca. Z tohto dôvodu bol vek primárne odhadovaný na základe stupňa zrastenia dlhých kostí a ich epifýz (Scheuer/Black 2004; Schaefer/Black/Scheuer 2009), hoci boli použité aj metódy hodnotiace morfologické zmeny symfýzy lonovej kosti (Brooks/Suchey 1990; Meindl a i. 1985; Todd 1930), aurikulárnej plôšky bedrovej kosti (Buckberry/Chamberlain 2002; Lovejoy a i. 1985) a sternálnych koncov rebier (DiGangi a $i$. 2009; İsçan/Loth 1986; İsçan/Loth/Wright 1984a; 1984b; 1985; Kurki 2005; Yoder/Ubelaker/Powell 2001). Stupeň zrastenia epifýz dlhých kostí, ako aj morfológia kostí, indikovali vek 15 až 19 rokov.

Výška postavy nebola vzhl'adom na vek jedinca hodnotená.

\section{Pozorované patologické zmeny}

U jedinca z hrobu 38 boli patologické zmeny pozorované na lebke, lopatkách, stavcoch, rebrách, dlhých kostiach horných i dolných končatín, kostiach rúk, chodidiel a na bedrových kostiach, pričom distribúcia lézií bola nápadne symetrická (obr. 3).

\footnotetext{
M. Ruttkay, ústna informácia z roku 2018.
} 


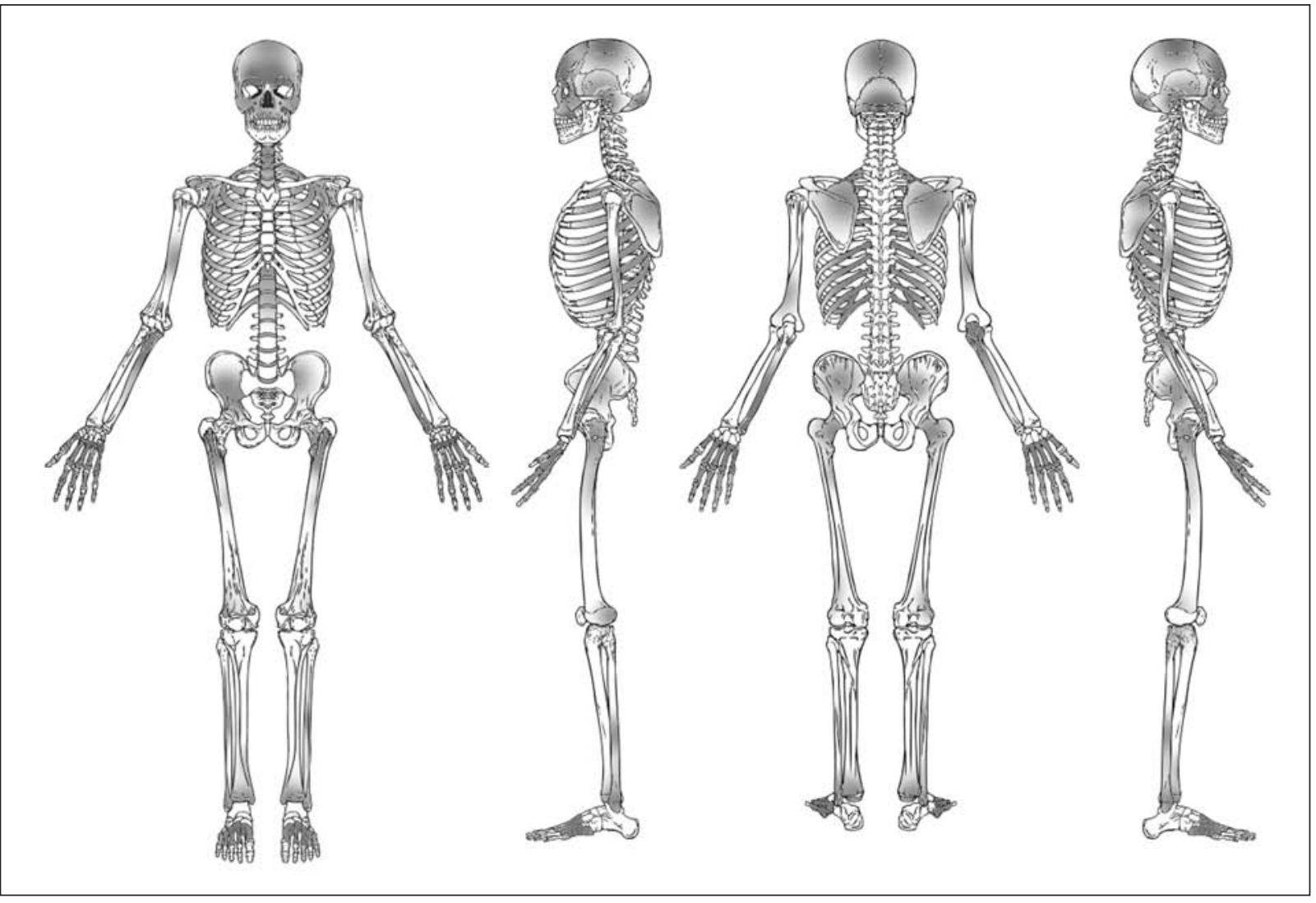

Obr. 3. Distribúcia patologických lézií na kostre jedinca z hrobu 38.

Na lebke sa nachádzali cribra orbitalia a cribra cranii a na čelusti boli okrem zvýšenej porozity viditelné aj viaceré ložiská aktívnej rozptýlenej periostitídy (obr. 4: 1). Na vnútornej strane lebečných kostí bola jasne viditel'ná vrstva novej kosti s belavým šedo-hnedým sfarbením ${ }^{4}$, s pozorovanými odtlačkami ciev - prejavmi serpens endocrania symmetrica (SES - odfarbená oblast’ kosti vykazujúca narušenie endokraniálneho povrchu, čím nadobúda vzhlad podobný bludisku; obr. 4: 5), na vnútornej strane frontálnej kosti sa nachádzala aj kruhová lytická lézia s priemerom približne $1 \mathrm{~cm}$. Kosti tvárovej časti lebky vykazovali známky zápalového procesu (obr. 4: 2). Na telách stavcov sa vyskytovali abnormálne kavitácie (štrbiny) a prejavy zvýšenej vaskularity (aktivity krvného obehu; obr. 4: 3). Hlavičky lavých rebier a vnútornú stranu lavých i pravých rebier pokrývala vrstva periostitídy (obr. 4: 4), celkovo boli lavé rebrá postihnuté do väčšej miery ako pravé. Diafýzy dlhých kostí rúk a nôh, záprstné kosti, priehlavkové kosti, ako aj články prstov rúk a chodidiel rovnako vykazovali znaky difúznej periostitídy (obr. 5: 1, 3). Zápalové prejavy sa prejavili aj na prednej strane lopatiek a na mediálnej strane bedrových kostí (obr. 5: 2).

\section{DISKUSIA}

Symetricky rozmiestnené ložiská periostitídy sú charakteristickým znakom hypertrofickej osteoartropatie (HOA). V prípade jedinca z hrobu 38 ide pravdepodobne o jej plúcnu formu - hypertrofickú plúcnu osteoartropatiu (HPO), kedže prítomnost periostitickej vrstvy na vnútornej strane rebier a kavitácia tiel stavcov naznačujú, že dotyčný jedinec vel'mi pravdepodobne trpel chronickým ochorením plúc. V súvislosti s HOA bola ako primárna príčina opakovane potvrdená tuberkulóza (TBC; Assis/Santos/Roberts 2011; Masson a i. 2013; Mays/Taylor 2002; Webb/Thomas 1986) a hoci spomínané lézie nemožno považovat’ za charakteristické výlučne pre plúcnu tuberkulózu, väčšina popisovaných zmien na rebrách

\footnotetext{
4 Najmä pozdíž sagitálneho švu a v oblasti záhlavnej kosti.
} 


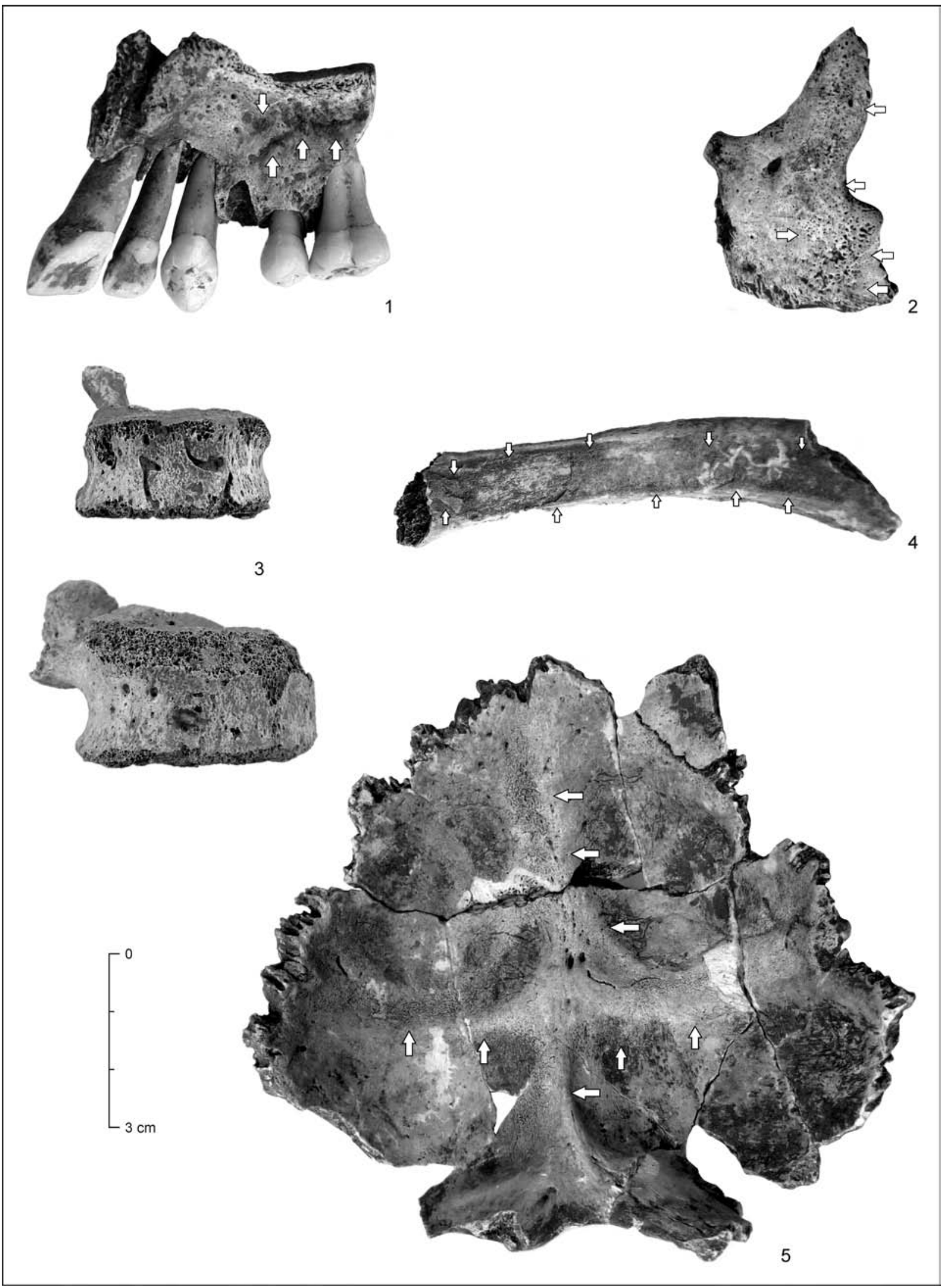

Obr. 4.1 - vrstva novej kosti na podnebí pravej čeluste, predná čast’ kosti vlavo; 2 - patologické zmeny na lavej lícnej kosti; 3 - hypervaskularizácia na telách stavcov; 4 - vrstva novej kosti na vnútornej strane rebier; hlavička rebra vlavo, kaudálna čast’ smeruje dolu; 5 - patologické zmeny na záhlavnej kosti; pohlad zvnútra, záhlavný otvor dolu. 


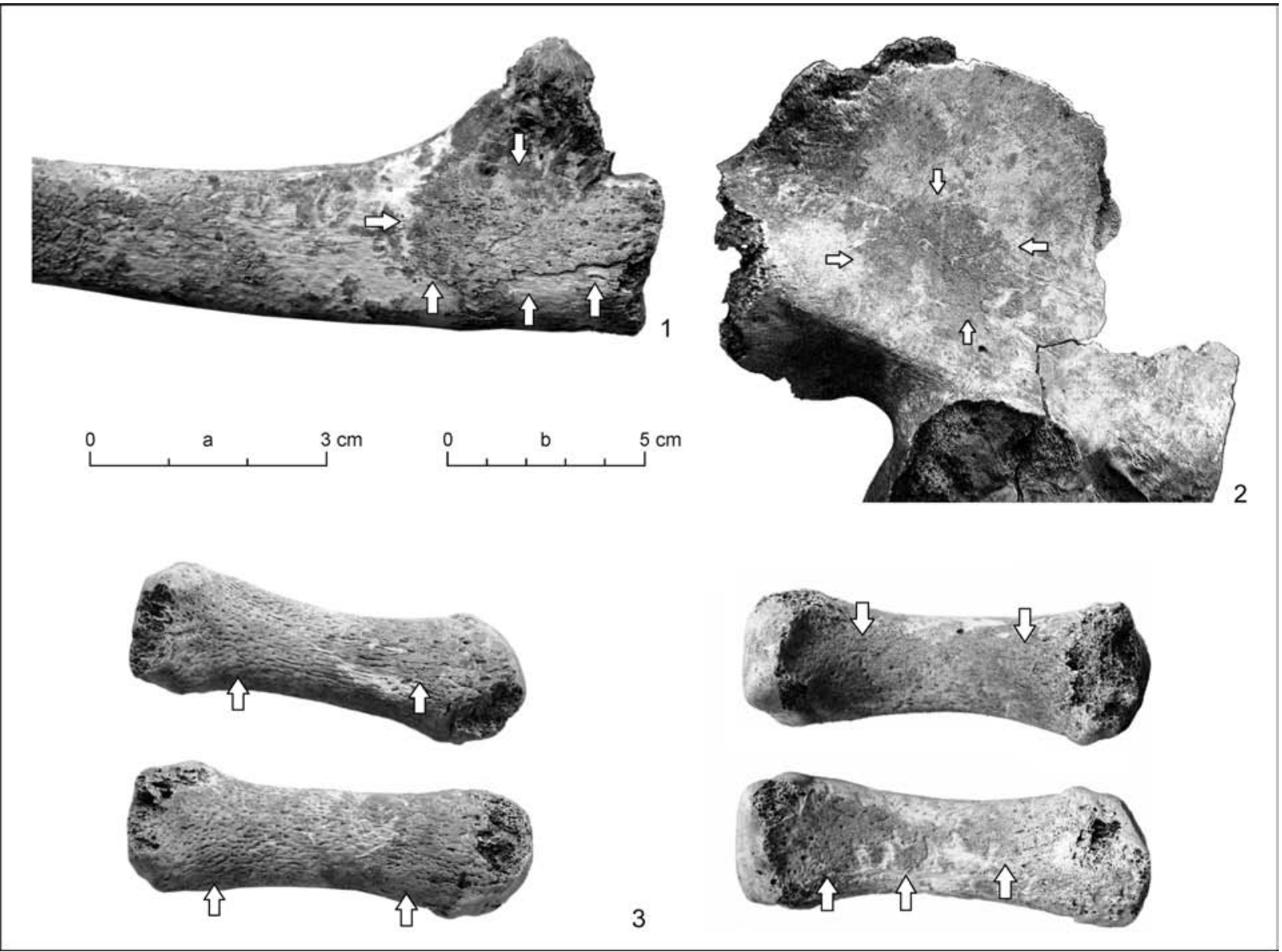

Obr. 5.1 - vrstva novej kosti na proximálnom konci pravej laktovej kosti; 2 - ložisko periostitídy na vnútornej časti bedrovej kosti; predná čast’ vpravo; 3 - patologické zmeny na prvých záprstných kostiach rúk; dorsálna strana vlavo, palmárna strana vpravo. Mierka: $\mathrm{a}-1,3 ; \mathrm{b}-2$.

sa často spája s jedincami trpiacimi práve plúcnou TBC (Matos/Santos 2006; Roberts 1999), najmä ak sú pozorované v lavej časti hrudníka. Mad’arská autorka M. Maczel (2003) skúmala znaky indikujúce skoré štádium tuberkulózy na kostre. Dnes sú tieto znaky známe pod označením MOLAT - Minor Osseous Lesions Attributable for Tuberculosis. Ide o súbor bližšie nešpecifikovatelných lézií na kostiach, ktoré predovšetkým v ich kombinácii možno pripísat práve tuberkulóze. Tieto patologické zmeny, vyskytujúce sa v skorších štádiách tuberkulózy, zahŕňajú vrstvu periostitídy na vnútornej strane rebier (Matos/Santos 2006; Roberts 1999), hypervaskularizáciu stavcov prejavujúcu sa nadmernou jamkovou koróziou po obvode tiel stavcov, pravdepodobne ako predispozíciou spinálnej tuberkulózy (Baker 1999; Ménard 1888), endokraniálne zmeny súvisiace s tuberkulóznou meningitídou (pozri tiež Hershkovitz a i. 1998; Schultz 1999; 2001) a už spomínané HOA (Maczel 2003). Ako je vidiet’ v tabele 2, kostra jedinca z hrobu 38 vykazovala všetky znaky MOLAT, pričom jednotlivé lézie boli dost’ výrazné (obr. 4-11). M. Maczel (2003) identifikovala MOLAT u všetkých vekových kategórií, predovšetkým však u nedospelých jedincov a mladých dospelých. S diagnózou tuberkulózy a s ňou spojenej HPO tak korešponduje aj vek jedinca z hrobu 38 z Nitry-Selenca II.

Napriek tomu, že MOLAT nemusia byṫ nevyhnutne patognomické pre tuberkulózu (Hershkovitz a i. 1998; Mays/Taylor 2002; Pfeiffer 1991; Rothschild/Rothschild 1998), M. Maczel (2003) uvádza, že v prípade prítomnosti viacerých z týchto lézií je len málo pravdepodobné, že by sa vyskytli naraz u jedného jedinca ako prejavy viacerých odlišných ochorení. Negatívne výsledky a nepotvrdenie diagnózy tuberkulózy u niektorých skúmaných jedincov pripisuje autorka najmä degradácii aDNA a absencii invazívnej baktérie v skúmanej vzorke (Maczel 2003). Zdá sa, že relevantnost výskumu M. Maczel, a teda aj pravdepodobnost', že u jedinca H38 by mohlo íst' o hypertrofickú plúcnu osteoartropatiu, spôsobenú pravdepodobne tuberkulózou, potvrdzujú aj výsledky d’alších bádatelov. Podobný prípad bol vd’aka 
Tabela 2. Patologické prejavy MOLAT (podla Maczel 2003) a patologické zmeny pozorované u jedinca z hrobu 38.

\begin{tabular}{|c|c|c|c|}
\hline \multicolumn{2}{|c|}{ Oblast' kostry } & Lézie MOLAT & $\begin{array}{l}\text { Lézie pozorované } \\
\text { u jedinca z hrobu } 38\end{array}$ \\
\hline \multirow{4}{*}{ Lebka } & \multirow{4}{*}{ endokranium } & belavé sfarbenie povrchu kosti & $\mathrm{x}$ \\
\hline & & abnormálne odtlačky krvných ciev & $\mathrm{x}$ \\
\hline & & hviezdicovitá endokraniálna reakcia & $\mathrm{x}$ \\
\hline & & vrstvy novej kosti s erozívnymi defektami a ostrými hranami & $\mathrm{x}$ \\
\hline \multirow{3}{*}{$\begin{array}{l}\text { Postkraniálny } \\
\text { skelet }\end{array}$} & rebrá & vrstva novej kosti na povrchu vnútornej časti rebier & $\mathrm{x}$ \\
\hline & stavce & hypervaskularizácia na telách stavcov (nápadná jamková korózia) & $\mathrm{x}$ \\
\hline & všetky kosti & rozsiahla difúzna periostitída, vrstva novej kosti na povrchu kostí, zvyčajne symetrická & $\mathrm{x}$ \\
\hline
\end{tabular}

porovnaniu s diagnostickými znakmi MOLAT zaznamenaný pred niekolkými rokmi na mad’arskej neolitickej lokalite Hódmezövásárhely-Gorzsa. Rovnako ako u jedinca H38, aj u mladej neolitickej ženy zo spomínanej mad’arskej lokality makroskopická analýza potvrdila rozsiahle symetrické ložiská periostitídy na dlhých kostiach a rebrách, indikujúce HOA, na základe čoho boli vykonané analýzy aDNA a lipidových biomarkerov potvrdzujúce tuberkulózu (Masson a i. 2013). Znaky HOA vykazovala aj kostra 12 mesačného dietata z Blízkeho východu (Hershkovitz a i. 2008), pričom u dietaata aj u mladej ženy z rovnakej lokality bola potvrdená aj prítomnost' Mycobacterium tuberculosis. U ženy bolo len málo fyzických indikátorov tuberkulózy, u dietata však boli pozorované viaceré typické lézie MOLAT, napríklad serpens endocrania symmetrica (SES) či periostitída na diafýzach dlhých kostí. Zo Slovenska sú tiež známe lokality s podobnými patologickými nálezmi. Na kostrových pozostatkoch v stredovekej populácii z Boroviec (8.-12. stor. n. 1.) a Devína-Hradu (11.-12. stor.) boli pozorované podobné prejavy počiatočných štádií tuberkulózy, pričom lézie taktiež prevládali u nedospelých jedincov (Kyselicová a $i$. 2015; 2016a). V súbore z Boroviec autori dokonca odhalili častý výskyt cribra orbitalia (u siedmich zo 16 jedincov išlo o kostry s prejavmi tuberkulózy). Cribra orbitalia a cribra cranii sa okrem iného spájajú aj s nutričným deficitom, ktorý sa môže vyvinút v dôsledku interakcie niekol'kých faktorov, medzi nimi napríklad odstavovanie od materského mlieka, nedostatočne bohatá strava, hygiena, parazity či infekčné choroby (Dupras/Trocheri 2007; King/Ulijaszek 1999; Lewis 2007; Lewis/Roberts 1997; Novak a i. 2018; Smrčka a i. 1989; Stuart-Macadam 1992; Walker 1986; Walker a i. 2009). Tuberkulóza tak predstavuje jednu z možných príčin cribra orbitalia a cribra cranii. Diagnostické znaky MOLAT (napr. preriedené telá stavcov a periostitické lézie) boli detegované aj na d’alších antropologických pozostatkoch z územia Slovenska, napr. vo Vel'kom Mederi (VondrákoválMatejovičová, v tlači), v Nesvadoch (Vondráková 1988) či na lokalite Nitra-Hrad (Krošláková 2015; Krošláková a i. 2019). Autori jednotlivých štúdií takisto poukazujú na pravdepodobné spojenie s tuberkulózou, avšak vo väčšine prípadov ide len o opisy individuálnych patologických zmien bez detailnejších analýz či diskusie ohladom súvislosti jednotlivých lézií. Na druhej strane, napríklad v súboroch z Nitry-Dražoviec (Kolena/Vondráková 2013, 153, 244, 256) alebo z lokality Cífer-Pác (Beňuš/Baldovič/Masnicová 2002; Kyselicováa a i. 2016b) boli zaznamenané aj patologické zmeny špecifické pre tuberkulózu, a to deficit kostného tkaniva tiel stavcov v kombinácii s tuberkulóznym hrbom, zrastením tiel stavcov, zápalom kosti a bezzápalového abscesu (Beňuš/Baldovič/Masnicová 2002; Kolena/Vondráková 2013, 153, 244, 256; Kyselicová a i. 2016b). Hoci nie vo všetkých prípadoch boli vykonané molekulárne analýzy, tieto nálezy indikujú, že tuberkulóza nemusela byt๋ v stredoveku na našom území vôbec výnimočným javom.

\section{ZÁVER}

Táto štúdia predstavuje nový pravdepodobný prípad hypertrofickej plúcnej osteoartropatie (HPO). Berúc do úvahy všetky analógie, diagnostické kritériá, pozorované patologické zmeny, ako aj silnú asociáciu HPO s tuberkulózou (najmä v jej tažkej neliečenej forme) a mladý vek muža z hrobu 38, je pravdepodobné, že primárnou príčinou osteoartropatie bola u jedinca z Nitry-Selenca II práve plúcna tuberkulóza. Tento nález tak obohacuje zoznam stále značne limitovaného zoznamu prípadov hypertrofickej osteoartropatie pozorovaných na ludských archeologických pozostatkoch. 


\section{LITERATÚRA}

Acsádi/Nemeskéri 1970

Assis/Santos/Roberts 2011

Baker 1999

Beňuš/Baldovič/Masnicová 2002

Blondiaux a i. 1992

Brickley/McKinley 2004

Brooks/Suchey 1990

Buckberry/Chamberlain 2002

Buikstra/Ubelaker 1994

Daňová 2013

Daňová/Ruttkay 2011

DiGangi a i. 2009

Dupras/Trocheri 2007

Elliot Smith/Ruffer 1910

Gladykowska-Rzeczycka/Prejzner 1993

Graw/Czarnetzki/Haffner 1999

Hershkovitz a i. 1998

Hershkovitz a i. 2008

İsçan/Loth 1986

Ïsçan/Loth/Wright 1984a

Ïsçan/Loth/Wright 1984 b
G. Acsádi/J. Nemeskéri: History of Human Life Span and Mortality. Akadémiai Kiadó. Budapest 1970.

S. Assis/A. L. Santos/C. Roberts: Evidence of hypertrophic osteoarthropathy in individuals from the Coimbra Skeletal Identified Collection (Portugal). International Journal of Paleopathology 1, 2011, 155-163.

B. Baker: Early manifestations of tuberculosis in the skeleton. In: G. Pálffi/ O. Dutour/J. Deák/I. Hutás (ed.): Tuberculosis. Past and present. Golden Book Publishers and Tuberculosis Foundation. Budapest - Szeged 1999, 301-309.

R. Beňuš/M. Baldovič/S. Masnicová: Pravdepodobný prípad tuberkulózy zo slovansko-avarského pohrebiska Cífer-Pác. Bulletin Slovenskej antropologickej spoločnosti pri SAV 5, 2002, 1-9.

J. Blondiaux/C.A. Baud/N. Boscher-Barré/C. Dardenne/N. Deschamps: Trace elements in palaeopathology. Quantitative analysis of a case of hypertrophic osteoarthropathy by instrumental neutron activation analysis. International Journal of Osteoarchaeology 2, 1992, 241-244.

M. Brickley/I. McKinley (ed.): Guidelines to the Standards for Recording Human Remains. Reading, BABAO, Department of Archaeology. Southampton 2004.

S.T. Brooks/J.M. Suchey: Skeletal age determination based on the os pubis: a comparison of the Acsádi-Nemeskéri and Suchey-Brooks methods. Human Evolution 5, 1990, 227-238.

J. Buckberry/A.T. Chamberlain: Age estimation from the auricular surface of the ilium. A revised method. American Journal of Physical Anthropology 119, 2002, 231-239.

J. Buikstra/D. H. Ubelaker: Standards for Data Collection from Human Skeletal Remains. Fayetteville 1994.

K. Daňová: Stredoveké pohrebisko z Nitry-Selenca. Rigorózna práca. Univerzita Konštantína Filozofa. Filozofická fakulta. Nitra 2013. Nepublikované.

K. Daňová/M. Ruttkay: Porušovanie hrobov v 11. storočí na pohrebisku v Nitre-Selenci. Acta Archaeologica Opaviensia 4, 2011, 161-197.

E.A. Digangi/J. Bethard/E. Kimmerle/L. Konigsberg: A new method for estimating age-at-death from the first rib. American Journal of Physical Anthropology 138, 2009, 164-176.

T. L. Dupras/ M. W. Tocheri: Reconstructing infant weaning histories at Roman period Kellis, Egypt, using stable isotope analysis of dentition. American Journal of Physical Anthropology 134, 2007, 63-74.

G. Elliot Smith/M. A. Ruffer: Pott'sche Krankheit an einer ägyptischen Mumie aus der Zeit der 21 Dynastie, um 1000 vor Chr., Heft 3 of Sudhoff and Sticker's Historische Biologie der Krankheitserreger. Giessen 1910.

J. J. Gladykowska-Rzeczycka/W. Prejzner: A case of probable pulmonary osteoarthropathy fom the Polish Mediaeval Cemetery of Czarna Wielka, District of Grodzisk. Journal of Paleopathology 5, 1993, 159-165.

M. Graw/A. Czarnetzki/H. T. Haffner: The form of the Supraorbital Margin as a Criterion in Identification of Sex from the Skull. Investigations Based on Modern Human Skulls. American Journal of Physical Anthropology 108, 1999, 91-96.

I. Hershkovitz/B. Rothschild/O. Dutour/C. Greenwald: Clues to recognition of fungal origin of lytic skeletal lesions. American Journal of Physical Anthropology 106, 1998, 47-60.

I. Hershkovitz/H. D. Donoghue/D. E. Minnikin/G. S. Besra/O. Y. Lee: Detection and Molecular Characterization of 9000-Year-Old Mycobacterium tuberculosis from a Neolithic Settlement in the Eastern Mediterranean. PLoS One 3, 2008. Dostupné na: https://journals.plos.org/plosone/article?id=10.1371/journal. pone.0003426 [22. 11. 2019]

M. Ïsçan/S. Loth: Determination of age from the sternal rib in white females. Journal of Forensic Sciences 31, 1986, 990-999.

M. Ïsçan/S. Loth/R. Wright: Metamorphosis at the sternal rib. A new method to estimate age at death in white males. American Journal of Physical Anthropology 65, 1984, 147-156.

M. Ïsçan/S. Loth/R. Wright: Age estimation from the rib by phase analysis, white males. Journal of Forensic Sciences 29, 1984, 1094-1104. 
Ïsçan/Loth/Wright 1985

King/Ulijaszek 1999

Kolena/Vondráková 2013

Krošláková 2015

Krošláková a i. 2019

Kurki 2005

Kyselicováa i. 2015

Kyselicováa a i. 2016 a

Kyselicová a i. $2016 b$

Lewis 2007

Lewis/Roberts 1997

Lovejoy a i. 1985

Maczel 2003

Martínez-Lavín 1997

Masson a i. 2013

Matos/Santos 2006

Mays/Taylor 2002

Meindl a i. 1985

Ménard 1888

Nayak a i. 2012

Novak a i. 2018

Palffi a i. 1999
M. Ïsçan/S. Loth/R. Wright: Age estimation from the rib by phase analysis. White females. Journal of Forensic Sciences 30, 1985, 853-863.

S. E. King/S. J. Ulijaszek: Invisible insults during growth and development. Contemporary theories and past populations. In: R. D. Hoppa/C. M. Fitzgerald (ed.): Human Growth in the Past. Studies from Bones and Teeth. Cambridge 1999, 161-182.

B. Kolena/M. Vondráková: Nitra-Dražovce. Osteologická analýza jedincov zo stredovekého pohrebiska z okolia Kostola sv. Michala Archanjela v Nitre-Dražovciach. Nitra 2013.

M. Krošláková: Nitra-Hrad - Námestie Jána Pavla II. Výskumná správa 18815. Archeologický ústav SAV. Nitra 2015. Nepublikované.

M. Krošláková/M. Vondráková/B. Kolena/P. Bednár: L'udské kostrové pozostatky $z$ nitrianskeho hradu (výskumy v rokoch 1988-2015). Nitra 2019.

H. Kurki: Use of the first rib for adult age estimation: a test of one method. International Journal of Osteoarchaeology 15, 2005, 342-350.

K. Kyselicová/R. Beňuš/M. Dörnhöferová/C. Bognár: Skeletal manifestation of tuberculosis in the medieval population of Borovce $\left(8^{\text {th }}-12^{\text {th }}\right.$ century AD, Slovakia) in relationship to the occurrence of long bone changes and cribra orbitalia. Česká Antropologie 65, 2015, 16-22.

K. Kyselicová/R. Beňuš/Cs. Bognár/M. Dörnhöferová: Anthropological evaluation of early skeletal tuberculosis in the medieval population of Devín-Castle $\left(11^{\text {th }}-12^{\text {th }}\right.$ century AD, Slovakia). Česká Antropologie 66, 2016, 20-25.

K. Kyselicová/L. Šebest/Cs. Bognár/M. Šarkan/M. Baldovič/R. Beňuš/L'. Kádaši: Molecular detection of Mycobacterium tuberculosis complex in the $8^{\text {th }}$ century skeletal remains from the territory of Slovakia. Biologia 71, 2016, 613-619.

M. E. Lewis: The Bioarchaeology of Children: Perspectives from Biological and Forensic Anthropology. Cambridge 2007.

M. E. Lewis/C. A. Roberts: Growing pains: the interpretation of stress indicators. International Journal of Osteoarchaeology 7, 1997, 581-586.

C. Lovejoy/R. Meindl/T. Pryzbeck/R. Mensforth: Chronological metamorphosis of the auricular surface of the ilium. A new method for the determination of adult skeletal age at death. American Journal of Physical Anthropology 68, 1985, $15-28$.

M. Maczel: On the Traces of Tuberculosis. Diagnostic criteria of tuberculosis affection of the human skeleton and their application in Hungarian and French anthropological series. Dizertačná práca. Univerzita Szeged 2003.

M. Martínez-Lavín: Hypertrophic osteoarthropathy. Current Opinion in Rheumatology 9, 1997, 83-86.

M. Masson/E. Molnár/H. D. Donoghue/G. S. Besra/D. E. Minnikin/H. H. Wu/ O. Y. Lee/I. D. Bull/G. Palffi: Osteological and biomolecular evidence of a 7000-year-old case of hypertrophic pulmonary osteopathy secondary to tuberculosis from Neolithic Hungary. PLoS One 8, 2013. Dostupné na: https:// journals.plos.org/plosone/article?id=10.1371/journal.pone.0078252 [22. 11. 2019] V. Matos/A. L. Santos: On the Trail of Pulmonary Tuberculosis Based on Rib Lesions: Results From the Human Identified Skeletal Collection From the Museum Bocage (Lisbon, Portugal). American Journal of Physical Anthropology 130, 2006, 190-200.

S. Mays/G. M. Taylor: Osteological and Biomolecular Study of Two Possible Cases of Hypertrophic Osteoarthropathy from Medieval England. Journal of Archaeological Science 29, 2002, 1267-1276.

R. Meindl/C. Lovejoy/R. Mensforth/R. A. Walker: A revised method of age determination using the os pubis, with a review and test of accuracy of other current methods of pubic symphyseal ageing. American Journal of Physical Anthropology 68, 1985, 29-45.

V. Ménard: Tuberculose vertébrale. Paris 1888.

H. K. Nayak/V. D. Rajkumar/N. Kumar/P. Kar: Primary hypertrophic osteoarthropathy (incomplete form) in young adults. A case report and review of literature. BMJ case reports, 2012. Dostupné na: https://www.ncbi.nlm.nih.gov/ pmc/articles/PMC4544915/ [22. 11. 2019]

M. Novak/V. Vyroubal/ Ž. Krnčević/M. Petrinec/R. Howcroft/R. Pinhasi/ M. Slaus: Assessing childhood stress in early mediaeval Croatia by using multiple lines of inquiry. Anthropologischer Anzeiger 75, 2018, 155-167.

G. Palffi/O. Dutour/G. Deák/I. Hutás: Tuberculosis. Past and present. Budapest 1999. 
Pfeiffer 1991

Phenice 1969

Pineda/Martínez-Lavín 2013

Roberts 1999

Rogers/Saunders 1994

Rothschild/Rothschild 1998

Rothschild/Rothschild 1999

Ruttkay a i. 2013

Ruttkay a i. 2015a

Ruttkay a i. 2015 b

Santos/Roberts 2001

Schaefer/Black/Scheuer 2009

Scheuer/Black 2004

Schultz 1999

Schultz 2001

Smrčka a i. 1989

Stuart-Macadam 1992

Todd 1930

Vondráková 1988

Vondráková/Matejovičová, v tlači

Walker 1986

Walker a i. 2009

Webb/Thomas 1986

Yoder/Ubelaker/Powell 2001
S. Pfeiffer: Rib lesions and New World tuberculosis. International Journal of Osteoarchaeology 1, 1991, 191-198.

A. Phenice: A Newly Developed Visual Method for Sexing the Os Pubis. American Journal of Physical Anthropology 30, 1969, 297-301.

C. Pineda/M. Martínez-Lavín: Hypertrophic osteoarthropathy: what a rheumatologist should know about this uncommon condition. Rheumatic Disease Clinics of North America 39, 2013, 383-400.

C. Roberts: Rib lesions and tuberculosis: the current state of play. In: G. Pálffi/ O. Dutour/J. Deák/I. Hutás (ed.): Tuberculosis. Past and Present. Golden Book Publisher Ltd. Tuberculosis Foundation. Budapest - Szeged 1999, 311-316.

T. Rogers/A. S. Saunders: Accuracy of Sex Determination Using Morphological Traits of Human Pelvis. Journal of Forensic Sciences 39, 1994, 1047-1056.

B.M. Rothschild/C. Rothschild: Recognition of Hypertrophic Osteoarthropathy in Skeletal Remains. Journal of Rheumatology 25, 1998, 2221-2227.

B. M. Rothschild/C. Rothschild: Evolution of osseous/radiologic signs of tuberculosis. In: G. Pálffi/O. Dutour/J. Deák/I. Hutás (eds.): Tuberculosis. Past and Present. Budapest - Szeged 1999, 293-298.

M. Ruttkay/H. Baliová/M. Bielich/A. Bistáková/J. Ďuriš/M. Kopčeková/J. Haruštiak/M. Jakubčinová/R. Malček/V. Mitáš/M. Vojteček: Záchranné archeologické výskumy na trase výstavby rýchlostnej cesty R1 v úseku Nitra-Selenec - Beladice. AVANS v roku 2009, 2013, 209-223.

M. Ruttkay/A. Bistáková/K. Daňová/M. Gabulová/M. Cheben/R. Malček: Záchranné archeologické výskumy na trase výstavby rýchlostnej cesty R1 v úseku Nitra-Selenec - Beladice. AVANS v roku 2010, 2015, 211-215.

M. Ruttkay/M. Bielich/K. Daňová: Záchranné archeologické výskumy na trase výstavby rýchlostnej cesty R1 v úseku Nitra-západ - Selenec. AVANS v roku 2010, 2015, 208-210.

A. L. Santos/C. Roberts: A Picture of Tuberculosis in Young Portuguese People in the Early $20^{\text {th }}$ Century: A Multidisciplinary Study of the Skeletal and Historical Evidence. American Journal of Physical Anthropology 115, 2001, 38-49.

M. C. Schaefer/S. Black/L. Scheuer: Juvenile Osteology. A Laboratory and Field Manual. London 2009.

L. Scheuer/S. Black: The Juvenile Skeleton. New York 2004.

M. Schultz: The role of tuberculosis in infancy and childhood in prehistoric and historic populations. In: G. Pálffi/O. Dutour/J. Deák/I. Hutás (eds.): Tuberculosis. Past and present. Budapest 1999, 501-507.

M. Schultz: Paleohistopathology of bone. A new approach to the study of ancient diseases. Yearbook of Physical Anthropology 44, 2001, 106-147.

V. Smrčka/V. Horn/M. Salaš/ J. Loosova: Porous hyperostosis and signs of cannibalism at the Blucina locality in southern Moravia (Czechoslovakia) in the Early Bronze Age. Paleobios 5, 1989, 5-15.

P. Stuart-Macadam: Porotic hyperostosis. A new perspective. American Journal of Physical Anthropology 87, 1992, 39-47.

T. Todd: Age changes in the pubic bone VIII. Roentgenographic differentiation. American Journal of Physical Anthropology 14, 1930, 255-271.

M. Vondráková: Nesvady-Rokalyuk, okr. Komárno. Výskumná správa 12.233/88. Archeologický ústav SAV. Nitra 1988. Nepublikované.

M. Vondráková/B. Matejovičová: Vel'ký Meder (Čalovo). Antropologický rozbor pohrebiska z obdobia Avarského kaganátu na Slovensku, v tlači.

P. L. Walker: Porotic hyperostosis in a marine-dependent California Indian population. American Journal of Physical Anthropology 69, 1986, 345-354.

P. L. Walker/R. R. Bathurst/R. Richman/T. Gjerdrum/V. A. Andrushko: The causes of porotic hyperostosis and cribra orbitalia: a reappraisal of the iron-deficiency anemia hypothesis. American Journal of Physical Anthropology 139, 2009, $109-125$

J. G. Webb/P. Thomas: Hypertrophic Osteoarthropathy and Pulmonary Tuberculosis. Tubercle 67, 1986, 225-228.

C. Yoder/D. Ubelaker/J. F. Powell: Examination of variation in sternal rib end morphology relevant to age assessment. Journal of Forensic Sciences 46, 2001, $223-227$. 


\title{
Hypertrophic pulmonary osteoarthropathy (HPO) as a secondary manifestation of probable tuberculosis in the skeleton of a young man from Nitra-Selenec II
}

\author{
Zuz a n a Hukel'ová
}

Summary

\begin{abstract}
Macroscopic analysis of the remains of an adolescent male (15-19 years) from grave 38 from the $11^{\text {th }}$ century cemetery at Nitra-Selenec II revealed extensive symmetrical inflammatory changes on the skull, ribs, scapulae, long bones, bones of hands and feet and pelvis, corresponding with the manifestations of hypertrophic osteoarthropathy (HOA). Additionally, signs of serpens endocrania symmetrica were observed on the skull, and abnormal cavitation and increased vascularity were indicated on vertebral bodies.

As a disease, HOA rarely occurs on its own and is usually secondary to lung, heart, liver or intestinal disease (Nayak a i. 2012; Pineda/Martínez-Lavin 2013). However, it is most frequently associated with lung diseases, which is known as hypertrophic pulmonary osteoarthropathy (HPO). Untreated tuberculosis (TB) has been repeatedly confirmed as the primary cause of this syndrome (Mays/Taylor 2002; Webb/Thomas 1986). The skeleton from Selenec II manifested all osseous lesions indicating an early stage of tuberculosis on the skeleton (known as MOLAT), including HOA. Taking into account similar cases reported in the world, diagnostic criteria, observed pathological changes, as well as the strong association of HPO with tuberculosis (especially with its severe untreated form) and the young age of the individual from Nitra-Selenec II, it is likely that pulmonary tuberculosis was the primary cause of HPO recorded in the man from grave 38 .

Overall, only a few cases of HOA/HPO have been identified in archaeological populations. There are known cases from Hungary (Masson a i. 2013), France (Blondiaux a i. 1992), Poland (Gladykowska-Rzeczycka/Prejzner 1993) Israel (Hershkovitz a i. 2008) or Mexico (Martínez-Lavin 1997). The individual from Slovakia therefore represents another exceptional case of hypertrophic osteoarthropathy observed in human archaeological remains.
\end{abstract}

Fig. 1. Location of Nitra-Selenec II. Available from: https://www.google.com/maps/search/nitra-selenec+mapa/ $@ 48.3059043,18.1355456,1217 \mathrm{~m} /$ data=!3m1!1e3?hl=sk [22. 11. 2019]

Fig. 2. Position of the individual in the grave (after Daňová 2013).

Fig. 3. Distribution of pathological lesions observed in individual from grave 38

Fig. 4.1 - periosteal lesion on the right maxilla; anterior side is on the left; 2 - pathological changes observed on the left zygomatic bone; 3 - hypervascularization of the vertebral bodies 4 - periostitis on the ventral side of the ribs; the rib head is on the left, inferior margin is down; 5 - pathological changes observed on the occipital bone; endocranial view, foramen magnum is down.

Fig. 5.1 - periostitis on the proximal end of the right ulna; 2 - periosteal lesion on the inner side of the left ilium; anterior end is right; 3 - pathological changes in the first metacarpals; dorsal view on the left, palmar view on the right. Scale: $\mathrm{a}-1,3 ; \mathrm{b}-2$.

Tab. 1. HOA/HPO cases in archaeological populations around the world.

Tab. 2. Pathological manifestations attributable to tuberculosis (according to Maczel 2003) and pathological changes observed in individual from the grave 38 .

Jazyková redaktorka Miriama Nemergutová

Translated by author

Bc. Zuzana Hukelová, MSc., PhD.

Archeologický ústav SAV

Akademická 2

SK - 94921 Nitra

hukelova.zuz@gmail.com 